\title{
Prevalence of impacted mandibular third molars among patients attending the dentomaxillofacial radiology clinic
}

\author{
Sanjit Singh A/L Munjit Singh*, Suhardjo*, Belly Sam* \\ *Department of Dentomaxillofacial Radiology Faculty Of Dentistry Universitas \\ Padjadjaran
}

\begin{abstract}
Introduction: The third molar is undoubtedly the most variable tooth in the human dentition, and also the most common tooth to become impacted due to it being the last tooth to erupt into the dental arch The aim of research is to obtain the prevalence of the mandibular third molar (M3) impaction among the patients attending the Radiology Clinic. Methods: The type of research conducted was a descriptive research. The sampling was purposive, drawn from a population of 1451 digital panoramic radiographs taken from January - December in the year 2010, of which 392 samples were included in the survey, with patient ages ranging between 18 - 59 years at time of exposure. The position of the M3's was assessed using the Pell and Gregory and, Winter's impaction classification. Results: The prevalence of impacted mandibular M3's in this study is $76.8 \%$ overall. Of the impacted mandibular M3's present, $76.1 \%$ were bilateral impactions and of these bilateral impactions $50.7 \%$ are similar in impaction classification. Of the mandibular M3's examined, $40.1 \%$ are in a vertical angulation, $33.3 \%$ mesioangular, $23.5 \%$ horizontal and $3.1 \%$ distoangular. The three most common types of impaction according to the Pell and Gregory classification are IIB at 38.5\%, IA at 36.8\% and IIA at 18.8\%. Conclusion: Prevalence of mandibular third molar of the patients attending the Radiology Clinic is $76.8 \%$.
\end{abstract}

Keywords: Impacted third molars, Panoramic radiography, Prevalence

\section{INTRODUCTION}

In recent years the third molar tooth has piqued the interest of dentists who have tried to pin it down to being the cause of a variety of dental problems as well as oral biologists who are trying to unravel its place in the human dentition. The third molar is undoubtedly the most variable tooth in the human dentition, and also the most common tooth to become impacted due to it being the last tooth to erupt into the dental arch. ${ }^{1}$

The third molars have a controversial place in the history and evolution of the human dentition. Some scientists and anthropologists view the third molars as a vestigial tooth on the verge of disappearing from the dentition.

In the opinion of William K. Gregory in his paper published in 1920, this has been explained as being due to in part of man's switching to a softer, cooked diet that relies less on chewing than previously and also his increased use of weapons and reduced dependent on teeth as weapons.

Also some academics state that in prehistoric man, tooth loss in man was more prevalent than today and the third molars erupting late in the growth and development of man serve as a replacement for any missing molars. Man's evolution favoring an ever decreasing dental arch length can 
also lend support the first claim that the third molars are a vestigial dental remnant with no functional use or space to erupt. ${ }^{2,3} \mathrm{An}$ impacted tooth is defined as one that is prevented from erupting into position because of malposition, lack of space, or other impediments. ${ }^{4}$ Third molars are the teeth that are most often impacted accounting for $98 \%$ of all impacted teeth according to Alling C.C et al. Kalle Aitasalo and his colleagues in 1972, from their study of impacted teeth in the Finnish patient population found that $76.1 \%$ of all impacted teeth were third molars.

More recently in 2003, a study conducted by F.C.S Chu et al in Hong Kong found a total of 28.3\% patients presented with at least one impacted tooth with, mandibular third molars were the most common at $82.5 \%$. From these studies it can be said that the mandibular third molar is a tooth that is very likely to be impacted.

To date, only two prior studies were done on the impaction of the third molars in Universitas Padjadjaran. The first was done in 1987, 24 years ago and the other in 1994, 17 years ago. Both these studies were conducted in Rumah Sakit Hasan Sadikin at the Oral Surgery Department located there.

The first study done in 1987 showed an impaction prevalence of $47.0 \%$ from a sample of 357 patients. The second study, done in 1994 describes IIB as the most common type of impaction from a sample of 92 patients.

The author has tried to locate similar studies conducted in other universities in Indonesia but has so far only located one study about the impaction of third molars conducted in Universitas Indonesia in the year 1967 but was unable to access it. Most likely studies conducted in other universities were not published and hence unable to be located.

Therefore there is no recent authentic data on the prevalence of mandibular third molar impaction currently available on the patients who have come for treatment at Rumah Sakit Gigi dan Mulut, Fakultas Kedokteran Gigi, Bandung or in other parts of Indonesia at the present point in time.

Rumah Sakit Gigi dan Mulut, Fakultas Kedokteran Gigi, Bandung (RSGM) was selected as the location of the research for numerous reasons.
Firstly no prior research survey had been done before on the topic of impacted third molars at this dental hospital. Secondly RSGM, Fakultas Kedokteran Gigi was equipped with a digital panoramic $\mathrm{X}$-ray machine a few years ago and has panoramic radiograph data from the start of its operation till this present time stored in a hard drive attached to the machine.

As the author is an undergraduate completing his clinical program at RSGM, and with the limited time and resources available, RSGM was the best location to conduct a study such as this. Due to numerous reasons stated above, the author believes the time is ripe to renew and expand the research using new technology in the form of digital panoramic radiographs already available in the computer terminal attached to the panoramic x-ray machine installed at Rumah Sakit Gigi dan Mulut, Fakultas Kedokteran Gigi, Bandung, West Java, Indonesia.

The aim of research is to obtain the prevalence of the mandibular third molar (M3) impaction among the patients attending the Radiology Clinic.

\section{METHODS}

The type of research being done is a simple descriptive research, with a survey done on the sample from the population to collect data. A descriptive research is one that focuses on only a single variable, and attempts to clarify and define that variable as clearly as possible without any action on the object of the study. The variable selected is the prevalence of mandibular third molar impaction among the patients of Rumah Sakit Gigi dan Mulut, Fakultas Kedokteran Gigi, Bandung.

A cross-sectional survey was chosen instead of the longitudinal survey, due to time constraints and limited resources available to the author. In the case of this research, the time frame for the cross-sectional survey was the all digital panoramic radiographs taken in the year 2010.

Radiology Installation in Rumah Sakit Gigi dan Mulut, Fakultas Kedokteran Gigi, Bandung. A descriptive research has one major weakness in the fact that it cannot analyze how one variable is related or affected by another different variable. 


\section{RESULTS}

The survey was done in Rumah Sakit Gigi dan Mulut, Fakultas Kedokteran Gigi, Bandung in mid-January till early February 2011. All panoramic radiographs taken for the year 2010 were examined on the computer attached to the Panoramic Machine. The result of this research is the prevalence of third molar impactions in the patient-population of Rumah Sakit Gigi dan Mulut,

Figure 1. Sample Distributions According to Age within the Parameters of the Survey

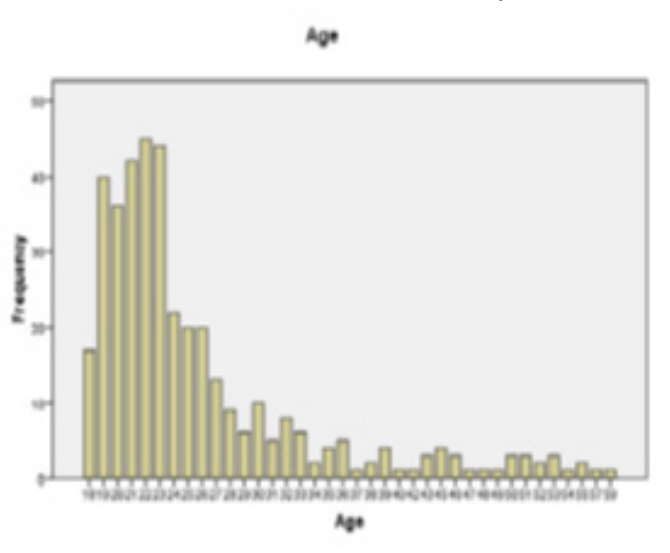

Fakultas Kedokteran Gigi, Bandung. Based on the survey that was conducted, the result from the data is presented in the following tables and charts as shown below.; In this study the total number of samples that were taken for this research is $\mathbf{3 9 2}$ panoramic radiographs. These radiographs are those that fall within the sample selection criteria stated in the research methodology chapter of this research. Based on selection criteria, the sample for this research included panoramic radiographs from 392 patients, aged between 18 to 59 years old. The mode for the sample was the age 22 years which has 45 panoramic radiographs. Chart 4.1 shows the sample age versus its frequency. The frequency of the sample age wise shows a tendency towards the lower quarter range of the sample age.

Table 1. Sample Distribution According to Gender within the Parameters of the Survey in the Patient-Population of RSGM,Fakultas Kedokteran Gigi, Bandung for the Year 2010

\begin{tabular}{ccccc}
\hline Gender & Frequency & Percent & $\begin{array}{c}\text { Valid } \\
\text { Percent }\end{array}$ & $\begin{array}{c}\text { Cumulative } \\
\text { Percent }\end{array}$ \\
\hline Female & 244 & 62.2 & 62.2 & 62.2 \\
Male & 148 & 37.8 & 37.8 & 100.0 \\
\hline Total & 392 & 100.0 & 100.0 & \\
\hline
\end{tabular}

Table 1 shows the percentage of male and female samples that were included for this survey. Based on table 2, $62.2 \%$ of the sample was female whereas $37.8 \%$ of the sample was male.

Table 2. Sample Mean and Standard Deviation according to Gender and Age in the Patient-Population of RSGM, Fakultas Kedokteran Gigi, Bandung for the Year 2010

\begin{tabular}{cccc}
\hline Gender & Mean & N & Std. Deviation \\
\hline Female & 24.87 & 244 & 7.885 \\
Male & 27.10 & 148 & 8.691 \\
\hline Total & 25.71 & 392 & 8.259 \\
\hline
\end{tabular}

Table 2 shows the mean and standard deviation of the sample population. Based on table 3 , the mean age for the sample population is 25.71 years old with a standard deviation of 8.259.

The data of third molar angulation, Pell and Gregory Classes 1, 2 and 3, and Pell and Gregory Classes A, B and C for both region 3 and 4 of the mandible is needed to observe the impaction status of the mandibular third molars in the patient population of Rumah Sakit Gigi dan Mulut, Fakultas Kedokteran Gigi, Bandung.

Table 3. Percentage of Mandibular Third Molar Impaction whether Unilateral or Bilateral in the Patient-Population of RSGM, Fakultas Kedokteran Gigi Bandung in the Year 2010

\begin{tabular}{ccc}
\hline Impaction Status & Frequency $(\mathbf{N})$ & Percentage (\%) \\
\hline Non Impacted M3 & 91 & 23.2 \\
Impacted M3 & 301 & 76.8 \\
\hline Total 392 100 & Total 392 100 & Total 392 100 \\
\hline
\end{tabular}

Table 4. Mandibular Third Molar Impaction Status in the Patient-Population of RSGM, Fakultas Kedokteran Gigi, Bandung for the Year 2010

\begin{tabular}{ccccc}
\hline $\begin{array}{l}\text { Impaction } \\
\text { Status }\end{array}$ & Frequency & Percent & $\begin{array}{c}\text { Valid } \\
\text { Percent }\end{array}$ & $\begin{array}{c}\text { Cumulative } \\
\text { Percent }\end{array}$ \\
\hline $\begin{array}{c}\text { Unilateral } \\
\text { Impaction }\end{array}$ & 72 & 18.4 & 18.4 & 18.4 \\
$\begin{array}{c}\text { Bilateral } \\
\text { Impaction }\end{array}$ & 113 & 28.8 & 28.8 & 47.2 \\
$\begin{array}{c}\text { Bilateral } \\
\text { Similar } \\
\text { Impaction }\end{array}$ & 116 & 29.6 & 29.6 & 76.8 \\
$\begin{array}{c}\text { Not Im- } \\
\text { pacted }\end{array}$ & 91 & 23 & 23 & 100 \\
\hline Total & 392 & 100.0 & 100.0 & \\
\hline
\end{tabular}

Table 3 shows the percentage of mandibular third molar impaction in the patient population of Rumah Sakit Gigi dan Mulut, Fakultas Kedokteran 
Gigi, Bandung. The percentage of third molar impaction in patients of Rumah Sakit Gigi dan Mulut, Fakultas Kedokteran Gigi, Bandung is $76.8 \%$.Table 4 contains the mandibular third molar impaction status for the patient population of Rumah Sakit
Gigi dan Mulut, Fakultas Kedokteran Gigi, Bandung. The total percentage of unilateral impaction is $18.4 \%$, the total percentage of bilateral impaction is $28.8 \%$, and the total percentage of bilateral similar impaction is $29.6 \%$ of the overall sample.

Table 5. Mandibular Third Molar Impaction Status According to the Female Gender in the Patient-Population of RSGM, Fakultas Kedokteran Gigi, Bandung for the Year 2010

\begin{tabular}{ccccc}
\hline Impaction Status & Frequency & Percent & Valid Percent & Cumulative Percent \\
\hline Unilateral Impaction & 35 & 14.3 & 14.3 & 14.3 \\
Bilateral Impaction & 66 & 27.1 & 27.1 & 41.4 \\
Bilateral Similar Impaction & 85 & 34.8 & 34.8 & 76.2 \\
Not Impacted & 58 & 23.8 & 23.8 & 100.0 \\
\hline Total & $\mathbf{2 4 4}$ & $\mathbf{1 0 0 . 0}$ & $\mathbf{1 0 0 . 0}$ & \\
\hline
\end{tabular}

Table 6. Mandibular Third Molar Impaction Status According to the Male Gender in the Patient-Population of RSGM, Fakultas Kedokteran Gigi, Bandung for the Year 2010

\begin{tabular}{ccccc}
\hline Impaction Status & Frequency & Percent & Valid Percent & Cumulative Percent \\
\hline Unilateral Impaction & 37 & 25.0 & 25.0 & 25.0 \\
Bilateral Impaction & 47 & 31.7 & 31.7 & 56.7 \\
Bilateral Similar Impaction & 31 & 21.0 & 21.0 & 77.7 \\
Not Impacted & 33 & 22.3 & 22.3 & 100.0 \\
\hline Total & 148 & 100.0 & 100.0 &
\end{tabular}

Table 7. Percentages of Third Molar Angulations from the Sample Surveyed

\begin{tabular}{cccc}
\hline Angulation & Frequency & Percent & Cumulative Percent \\
\hline Distoangular & 25 & 3.2 & 3.2 \\
Horizontal & 184 & 23.5 & 26.7 \\
Mesioangular & 261 & 33.3 & 60.0 \\
Vertical & 314 & 40.1 & 100.0 \\
\hline Total & $\mathbf{7 8 4}$ & 100.0 & \\
\hline
\end{tabular}

Table 7 shows the most common type of impaction for the mandibular third molars overall without taking into account regions of impaction. From the table above it can be seen that the most com- mon angulation is vertical accounting for $40.1 \%$, followed by mesioangular with $33.3 \%$, and continues with horizontal being the third most common with $23.5 \%$, finally distoangular with $3.2 \%$.

Table 8. Percentages of Third Molar based on the Pell and Gregory Classification from the Sample Surveyed

\begin{tabular}{cccc}
\hline Classification & Frequency & Percent & Cumulative Percent \\
\hline IA & 288 & 36.8 & 36.8 \\
IB & 19 & 2.4 & 39.2 \\
IIA & 147 & 18.8 & 58.0 \\
IIB & 302 & 38.5 & 96.5 \\
IIC & 7 & 0.9 & 97.4 \\
IIIA & 1 & 0.1 & 97.5 \\
IIIB & 4 & 0.5 & 98.0 \\
IIIC & 16 & 2.0 & 100.0 \\
\hline Total & 784 & 100.0 & \\
\hline
\end{tabular}


Table 8 shows the most common type of mandibular third molar impaction according to classification without taking into account the regions of impaction. From the table above it can be seen that the most common classification for an impacted mandibular third molar is IIB with a percentage of $38.5 \%$, and closely followed by IA with $36.8 \%$. The three Pell and Gregory classification with the least amount impacted teeth in this survey are by decreasing order, IIC, IIIB and IIIA.

\section{DISCUSSION}

In this study the mode age of the sample was 22 years which is quite close to the average age of $20 .{ }^{3}$ years reported for the eruption of the third molars (Hellman M., 1936) Schersten et al suggested that 20 to 25 years is the most suitable age for studying the frequency of $M 3$ and its impaction. The reason for this is to avoid overestimation of M3 agenesis as a result of unnoticed early extraction in older group. Furthermore, many impacted $M 3$ can change their position and erupt after the age of 18 to 20 years. ${ }^{4,5,6,7}$

According to previous research, Hattab et al. reported that $33.6 \%$ of the population has at least one impacted third molar, with a frequency of $15.9 \%$ in the mandible. Björk et al.and Ventä et al. reported that the incidence of non-erupted third molars is between $22.3 \%$ and $66.6 \%$. Therefore the percentage of mandibular third molar impaction found in this research which is $76.8 \%$, can be stated as belonging to the higher range based on previous research.

It can be seen from the present study that the prevalence of mandibular third molar impaction in our sample of a patient population in the Dental Teaching Hospital of Universitas Padjadjaran for the year 2010 was $76.8 \%$, with nearly the same percentage of impactions in males and females, being $77.7 \%$ and $76.2 \%$. In a prior study conducted at Rumah Sakit Hasan Sadikin by another undergraduate from the dental faculty in 1987, the prevalence of impaction reported for the patients there were $47.0 \%$. Hellman reported on a study which showed $9.51 \%$ of the third molars impacted in male subjects and $23.8 \%$ impacted in females. Hellman attributed this to the fact that the jaws of females stop growing when third molars are just beginning to erupt, whereas, in males, the growth of the jaws continues beyond the time of eruption of the third molars. Bjork et al showed that third molar impaction was associated not only with reduced jaw growth but also the more downward rather than forward direction of growth. The proportion of impaction in males was $17.4 \%$ and in females $16.2 \%$ in a study done by F.N. Hattab on Jordanian students. There is not much difference in the prevalence of impacted wisdom teeth between male (34\%) and female (29\%) Saudi patients in the study done by Zohair Haidar and Suliman Y. Shalhoub In our study of the mandibular third molars alone, impactions showed a ratio of 50:50 between the sexes. Further research has to be done in order to prove whether there is any sexual dimorphism of impacted third molars among the sexes.

However of the impacted mandibular third molars present, $76.1 \%$ were bilaterally impactions and of these bilateral impactions $50.7 \%$ were similar in impaction classification. This is an interesting pattern and the reason for similar bilateral impactions may lie in part with the similar genetic and physiologic processes of the developing third molars buds. Further research must be done before more can said on this unexpected result. Of the mandibular third molars examined in this study, $40.1 \%$ were in a vertical position, $33.3 \%$ were in a mesioangular position, $23.5 \%$ were in a horizontal position and $3.1 \%$ were in a distoangular position. In the study done by Sumeet S. et al, $49 \%$ of the mandibular M3s were found to be in the mesioangular position. This number is relatively higher than that reported by Sewerin and Von Wowern $(18 \%)$. In our observation that $40.1 \%$ of the lower $M 3$ were in vertical position is more than that reported by Hattab et al (39\%), and Kruger et al (11.9\% at age 18$)$. At the current moment, no research done has come to any conclusions about reason for impacted third molar angulation.

The impaction rate of mandibular third molars among patients at Rumah Sakit Gigi dan Mulut Fakultas Kedokteran Gigi is $76.8 \%$ of the 392 panoramic radiographs examined. This is alarmingly high when compared to the results of other similar studies. The reason for the high prevalence of impacted mandibular third molars cannot be attributed to just one factor but can be seen as a result of a myriad of factors interacting. In terms of jaw size, the Mongoloid people have on average 
smaller jaws than Caucasoid and Negroid people. In terms of teeth size (mesiodistal width), the Mongoloid people have the second largest set of teeth among the 3 races.

Diet in the modern world, is the common factor between developing and developed countries. In many cases a shift of a diet from has occurred from a rougher, fibrous diet low in sugar to a more refined, softer, western diet. The lack of attrition which results in the reduction of the mesio-distal width of teeth and frees up space

lack of physical stimulation of the jaw means the mandibular third molars erupt into a jaw lacking space and will likely be impacted.

It must be remembered that in this study digital panoramic radiographs were surveyed to assess the prevalence of mandibular third molar impaction. This means that a 3 dimensional structure was viewed in 2 dimensions. According to a study done by LFM Sant'Ana et al in 2005 which demonstrated that there is a mean alteration of approximately $5^{\circ}$ when measurements taken on panoramic radiographs are compared with those achieved on study casts obtained from transurgical impressions. With these results, it may also be stated that there is uniformity in these variations, demonstrating that the panoramic radiograph tends to exhibit a more mesial position of the third molars. Therefore the results of this research may be slightly skewed due to this inherent characteristic of panoramic radiographs and must be interpreted accordingly.

The use of panoramic radiographs has become widespread due to their ability to display a wide region of the patient's jaw, dentition and maxilla. This combined with the ease of interpretation and low radiation dosage means that panoramic radiographs are in a good position to be used as a form of early detection of impacted mandibular third molars.

Also using panoramic radiographs, impacted mandibular third molars can be classified and monitored. Although as mentioned above there is a slight mesial displacement tendency of the mandibular third molars viewed in the panoramic radiograph, this is not something invalidates its use for diagnosis of impaction. A more molars is that those that are severely bucco-linguoversed are not shown in detailed due to the fact that these teeth lie perpendicular to the focal trough of the panoramic radiograph. The ability to determine inferior alveolar never approximation of the roots of the impacted third molars also is difficult in a panoramic radiograph as these structures are 3 dimensional in the patient. The best way around this problem is through the use of Cone Beam Computer Tomography.

This study has demonstrated the prevalence of mandibular third molar impaction in the patients visiting the Radiology Clinic of Rumah Sakit Gigi dan Mulut Fakultas Kedokteran Gigi. In the cases of impactions that produce morbidity or the prophylactic removal recommendation of the third mandibular third molars, patients must undergo an odontectomy.

Third molar extraction is the most commonly performed procedure in the practice of oral and maxillofacial surgery. In addition, third molar extraction comes at great financial expense. In the United States alone, the amount spent each year for the extraction of third molars is estimated to be more than $\$ 2$ billion, excluding the costs of examinations, radiographs, medication, anesthesia or hospital or surgical theatre charges. ${ }^{8}$

The best prognosis for mandibular third molar removal with reduced chances inferior alveolar nerve damage is when the mandibular third molar roots are one-third to two-thirds formed. At this stage the roots are generally blunt and rarely fracture during removal. They are also not embedded as deep as teeth with fully formed roots and, thus, are most likely more distance away from vital structures when compared to teeth with long, fully formed roots. ${ }^{9}$ Mandibular third molar removal also should be carried when the patient is young, as the bone is young people is less calcified and more flexible, allowing for a less traumatic extraction. ${ }^{10,9}$

Some surgeons are of the opinion that the thid molar can be removed at the age of 7 to 9 with minimal surgical morbidity. As a patient ages, the response to surgical insult is tolerated less easily, the recuperation period grows longer more postoperative sequelae occur. There is overwhelming clinical evidence to support the fact that the number of days missed from work and other normal activity following third molar extraction is much higher in the patient over age 40 years compared with patients under age 18 years. ${ }^{10,9}$ Third molar enucleation at the age of 8 
years has been practiced in England since 1936 by Henry and Morant. Other surgeons are of the opinion that the third molars should be left until the time of their eruption, and removed only when the third molars cause morbidity. There have been some studies conducted about

A weakness of this study is that we were unable to assess the prevalence of the agenesis of the mandibular third molars which was part of the initial aim for this research. As the patient medical record system at the Dental Teaching Hospital of Universitas Padjadjaran was offline since a tropical storm caused a power surge, any mandibular third molars recorded as being missing in the digital panoramic radiographs were unable to be verified with their respective medical records.

The authors decided against continuing to attempt to research the agenesis of the mandibular third molars because of the unreliability of the results later on. Also another factor that was taken into consideration was the unreliability of the medical records in the Dental Teaching Hospital of Universitas Padjadjaran due to the fact that the patient medical records are frequently taken by 4th and 5 th year dentistry students.

The education level of the patients that attend the Dental Teaching Hospital of Universitas Padjadjaran also must be taken into account, as many patients come from lower-income social strata and may provide unreliable facts upon initial history taking.

\section{CONCLUSION}

Prevalence of mandibular third molar of the patients attending the Radiology Clinic is $76.8 \%$.

\section{REFERENCES}

1. Pitekova L, Satko I. Controversy of the third molars., Bratisl Lek Listy. 2009;2(1):110-111
2. Shiller WR. Positional changes in mesio-angular impacted mandibular third molars during a year. J Am Dent Ass. 1979;99(5):460-4.

3. Sewerin I, Wowern VN. A radiographic fouryear follow-up study of asymptomatic mandibular third molars in young adults. Int Dent J 40:24, 1990

4. Venta I, Murtomaa H, Turtola L, Meurman J, Ylipaavalniemi P. Clinical follow-up study of third molar eruption from ages 20 to 26 years. Oral Surg Oral Med Oral Pathol 1991; 72:150-3.

5. Richardson M. Changes in lower third molar position in the young adult L Am 30rthod Dentofacial Orthop 1992;102:320-7.

6. Flick, W.G. The third molar controversy: framing the controversy as a public health issue. $J$ Oral Maxillofac Surg. 1999;57(2):438-44

7. Michael M, Miloro GE, Ghali, Peter E. LarsenPD. Waite. Peterson's Principles of Oral and Maxillofacial Surgery, 2nd Edn Ontario : BC Decker Inc. 2004. 139-155.

8. James R, Hupp, Edward, Ellis III, Myron, Tucker R. Principles of Management of Impacted Teeth. In Contemporary Oral and Maxillofacial Surgery. St Louis: Mosby, Elsevier. 2008;153178 